\title{
Social and nutritional parameters of acute diarrhoea
}

\author{
UELI BOLLAG \\ Department of Gastroenterology, Children's Hospital Zurich, Switzerland
}

SUMMARY Data were collected on 60 children who were admitted for acute undifferentiated diarrhoea during a 5-month period to this hospital. Stool cultures for bacterial pathogens were all negative. Social and economic factors in the homes of the children were conspicuous.

Diarrhoea is a common reason for admitting children to hospital. Pathogenic factors include the infectious agent (if any), host resistance, and immunological deficits, but nutritional and socioeconomic factors can also have a great effect on the morbidity of acute diarrhoea-at least in developing countries. In the present investigation the role of socioeconomic and nutritional factors was studied in children with diarrhoeal disease in a developed and industrialised country.

\section{Methods}

Data were collected from the case histories of 60 patients admitted consecutively to this hospital for diarrhoeal disease during the 5 months from 1 January to 31 May 1977.

Nationality, conditions at home, marital status of the parents, and the care of the child served as parameters of the social background.

The child's nutritional status was assessed in terms of weight-for-age and height-for-age, which were related to the standards of Prader and Budliger. ${ }^{1}$ Weight-for-height was recorded, and the weight on admission was compared with that at discharge. Prematurity and weight for gestational age at birth were factors also taken into consideration.

\section{Results}

The overall distribution in terms of the child's age and sex is shown in the Figure. 24 out of 60 children came from families of foreign labourers (Table 1). 18 children came from unstable homes (Table 2). Seven children had either been born before 37 weeks' gestation, or had been small for gestational age (birthweight $<10$ th centile), Table 3 . The perinatal records for 6 children were missing.

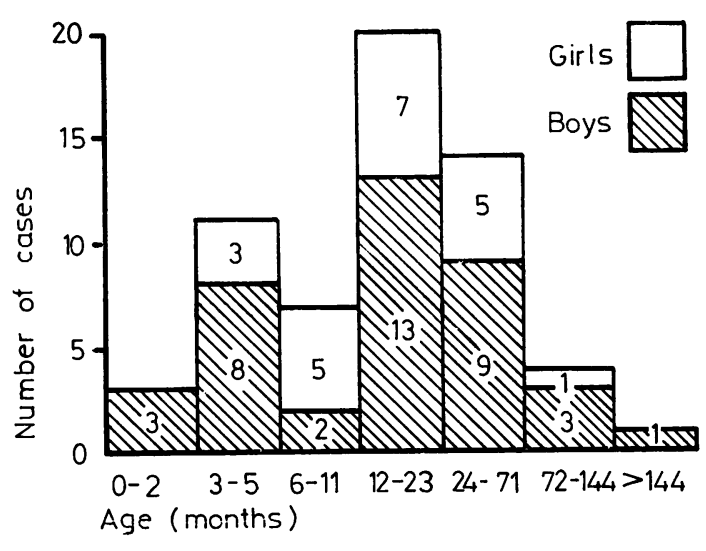

Figure Age and sex distribution of 60 children admitted for diarrhoeal disease.

Table 1 Nationality of 60 children suffering from diarrhoea

\begin{tabular}{ll}
\hline Nationality & Children \\
\hline Swiss & 36 \\
Italian & 13 \\
Spanish & 4 \\
Yugoslavian & 4 \\
Turkish & 2 \\
German & 1 \\
\hline
\end{tabular}

Table 2 Number of Swiss compared with foreign children from unstable homes

\begin{tabular}{lll}
\hline & $\begin{array}{l}\text { Foreign children } \\
(n=13)\end{array}$ & $\begin{array}{l}\text { Swiss children } \\
(n=5)\end{array}$ \\
\hline Nursing home/family & 1 & 1 \\
Day care centre (crèche) & 6 & 2 \\
Relatives & 3 & 1 \\
Parents away from & 2 & 1 \\
$\quad \begin{array}{l}\text { Switzerland for at } \\
\text { least a week }\end{array}$ & 1 & \\
Neglect & 1 & 0 \\
\hline
\end{tabular}


Table 3 Premature infants and those of birthweights below $2500 \mathrm{~g}$ compared with weight-for-height and height-for-age on admission and change in weight during admission

\begin{tabular}{|c|c|c|c|c|c|c|c|c|}
\hline \multirow{2}{*}{$\begin{array}{l}\text { Age } \\
\text { (months) }\end{array}$} & \multirow[t]{2}{*}{ Sex } & \multirow{2}{*}{$\begin{array}{l}\text { Gestational age } \\
\text { (weeks) }\end{array}$} & \multirow{2}{*}{$\begin{array}{l}\text { Birthweight } \\
(g)\end{array}$} & \multicolumn{4}{|c|}{ On admission } & \multirow{2}{*}{$\begin{array}{l}\text { Weight } \\
\text { change }\end{array}$} \\
\hline & & & & $\begin{array}{l}\text { Weight } \\
(g)\end{array}$ & $\begin{array}{l}\text { Weight } \\
\text { centile }\end{array}$ & $\begin{array}{l}\text { Height } \\
(\mathrm{cm})\end{array}$ & $\begin{array}{l}\text { Height } \\
\text { centile }\end{array}$ & \\
\hline $\begin{array}{c}18 \\
26 \\
27 \\
74 \\
38 \\
18^{*} \\
101\end{array}$ & $\begin{array}{l}\mathbf{F} \\
\mathbf{F} \\
\mathbf{M} \\
\mathbf{F} \\
\mathbf{F} \\
\mathbf{M} \\
\mathbf{M}\end{array}$ & $\begin{array}{l}40 \\
40 \\
36 \\
40 \\
40 \\
34 \\
\text { Premature }\end{array}$ & $\begin{array}{l}2500 \\
2500 \\
2490 \\
2500 \\
2500 \\
2400 \\
2500\end{array}$ & $\begin{array}{r}10150 \\
12000 \\
12250 \\
16150 \\
10400 \\
8300 \\
27700\end{array}$ & $\begin{aligned} & 25 \text { th } \\
& 25 \text { th-50th } \\
10 \text { th-25th } & \text { 3rd-10th } \\
< & \text { 3rd } \\
< & 3 \text { rd } \\
& 50 \text { th-75th }\end{aligned}$ & $\begin{array}{c}88 \\
90 \\
95 \\
117 \\
95 \\
72 \\
133 \cdot 5\end{array}$ & $\begin{array}{l}>97 \text { th } \\
75 \text { th } \\
90 \\
50 \\
25 \text { th-50th } \\
<3 \text { rd } \\
50 \text { th- } 75 \text { th }\end{array}$ & $\begin{array}{l}-370 \\
-300 \\
0 \\
+850 \\
? \\
+660 \\
0\end{array}$ \\
\hline
\end{tabular}

*Weight, and particularly height, well below the 3rd centile. Congenital hypothyroidism was excluded.

28 children were underweight on admission (weight $>1$ SD below the expected weight for height). The discharge weights of 16 children were lower than they had been on admission to hospital and in 3 children weights on discharge remained the same (Table 4).

The stools of all children admitted for diarrhoea were routinely screened three times for bacterial pathogens (enteropathogenic Escherichia coli, pathogenic Salmonella sp., and Shigella sp.) but not for viruses. All were negative.

\section{Discussion}

Boys were affected twice as often as girls. There were 21 infants below 1 year and 20 children aged between 1 and 2 years.

The total population of Switzerland was 6400000 in January 1977, of which foreigners accounted for 990000 . The proportion is somewhat different for the age group 0-14 years, with 1358000 children of Swiss parents and 280000 children of foreign parents. ${ }^{9} \mathrm{~A}$ disproportionate $40 \%$ of all children admitted for diarrhoea were still from the latter group. Most foreigners are labourers from Mediterranean countries; some are resident others are seasonal. They seek higher salaries, part of which is sent back to their families at home. As both mother and father work, children are often cared for elsewhere. The care a mother gives to her child is adversely affected by poverty and poor social conditions, ${ }^{2}$ and this together with abrupt changes in feeding in quality or quantity must put the children at risk for gastrointestinal upset.

Even if the nationality of the children were to te disregarded, the importance of such social factors is underlined by the fact that $30 \%$ of the 60 children came from unstable homes. Eight children stayed in a day care centre, 4 because both parents were working, and 4 because their parents were separated or divorced, or the mother was single. One child had been placed in a nursing home and 1 was with a different family. Three children whose parents were foreign labourers were taken care of by relatives, a feature of the extended family system of meridional people. 'Granny' protected a battered child of young Swiss parents. One 6-month-old boy who was obviously dirty and neglected on admission came from a Turkish family with 5 children below 10 years.

Low birthweight babies (preterm or retarded intrauterine growth) are known to adapt poorly to physiological insults in the neonatal period. Seven $(12 \%)$ of our group had low weights at birth, about double that in the Swiss population $;^{3} 5$ of them showed an obvious deficit in weight-for-height on admission.

This fact was also true for the whole group of 60 children, of whom $28(47 \%)$ were underweight on admission, although the heights of 23 of them were $>50$ th centile. Height-for-age can be looked on as indicating long-term previous dietary history, as opposed to weight-for-height which reflects the current nutritional status of the child. ${ }^{4}$ Thus half the children were in a fairly acute state of malnutrition.

This weight deficit did not merely reflect the acute state of dehydration, as shown by two observations. Firstly, the weights of many of the children, though rising during rehydration, dropped again when maintenance feeding was restored. Secondly, 17 $(28 \%)$ of the children weighed less at discharge than on admission, and $2(4 \%)$ showed a flat weight curve. We concluded that a substantial number of children were truly underweight before the acute disease, while some others were unable to cope with oral nourishment after they had been rehydrated. ${ }^{5}$

Thus it seems that the well-known pattern of 'malnutrition-diarrhoea' of poor countries is to a lesser degree also applicable to the so-called developed world, as far as special population groups are concerned.

Stool cultures in our cases showed no pathogens, but even if pathogens had been found, they would not 


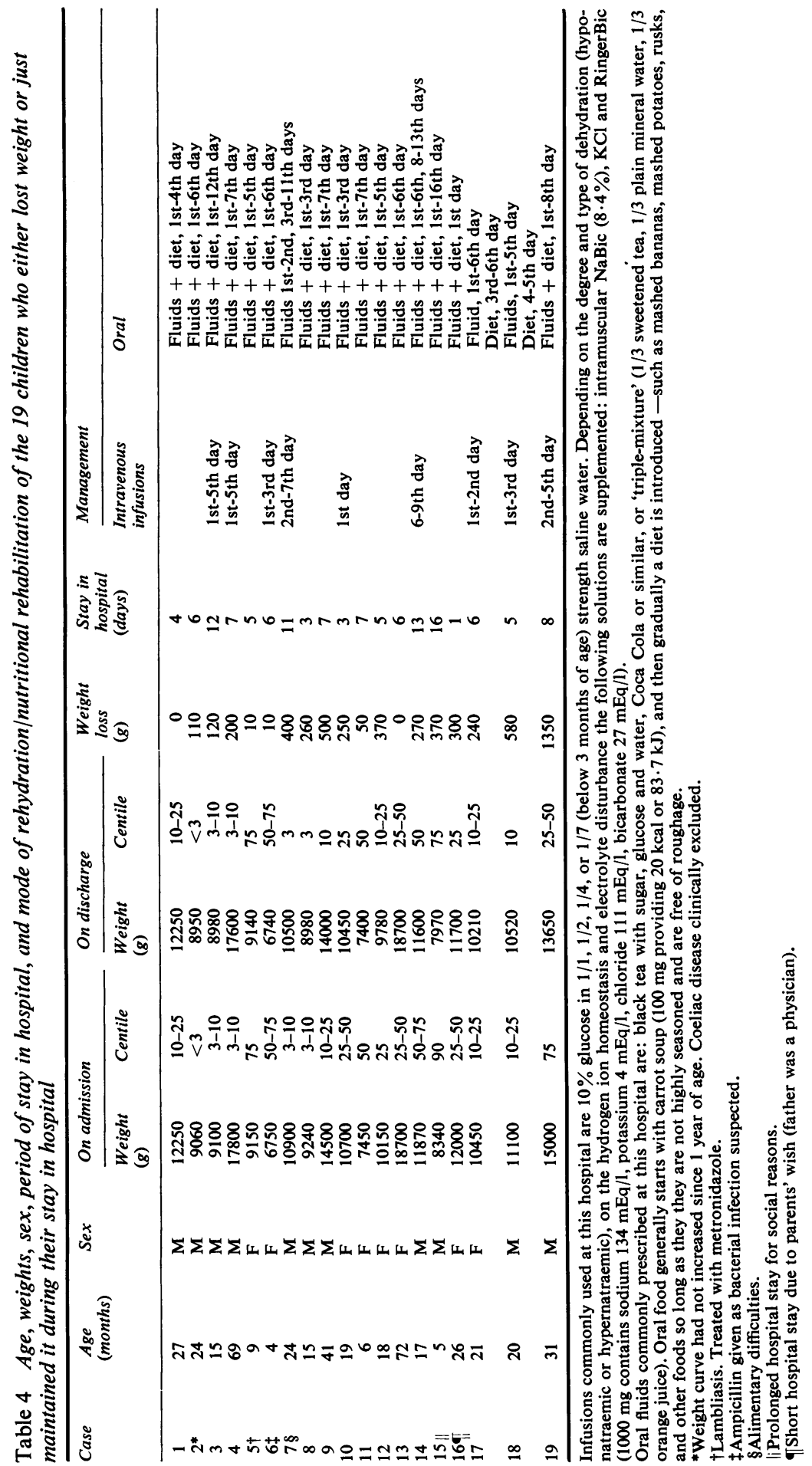


necessarily have been the cause of the diarrhoea. This fact has been repeatedly proved in the case of enteropathogenic $E$. coli, where many carriers are asymptomatic. ${ }^{6-8}$

\section{References}

1 Prader A, Budliger H. Körpermasse Wachstumsgeschwindigkeit und Knochenalter gesunder Kinder in den ersten zwölf Jahren (Longitudinale Wachstumsstudie Zürich). Helv Paediatr Acta 1977; Supplement 37.

2 Desai P, Standard K L, Miall W E. Socioeconomic and cultural influences on child growth in rural Jamaica. $J$ Biosoc Sci 1970; 2: 133-43.

3 Duc G. Mesures préventives de la mortalité néonatale et de la morbidité cérébrale associées à la prématurité. Gynaekol Rundsch 1975; 15: Supplement 1, 34-8.

4 Waterlow J C. Classification and definition of proteincalorie malnutrition. $\mathrm{Br}$ Med J 1972; iii : 566-9.

5 Waterlow J C, Golden M, Picou D. The measurement of rates of protein turnover, synthesis, and breakdown in man and the effects of nutritional status and surgical injury. Am J Clin Nutr 1977; 30: 1333-9.

6 Ramos-Alvarez M, Sabin A B. Enteropathogenic viruses and bacteria: role in summer diarrheal diseases of infancy and early childhood. $J A M A 1958 ; 167: 147-56$.

7 Solomon P, Weinstein L, Joresy S M. Studies of the incidence of carriers of enteropathogenic Escherichia coli in a pediatric population. J Pediatr $1961 ; 58: 716-21$.

8 Bollag U. Studies into the incidence of carriers of enteropathogenic E. coli. Trans $R$ Soc Trop Med Hyg 1978; 72: 588-91.

${ }^{9}$ Swiss Federal Board of Statistics, Berne; 1977.

Correspondence to Dr U Bollag, USC School of Medicine, Division of Research in Medical Education, 1975 Zonal Avenue, Los Angeles, California 90033, USA.

Received 13 July 1979 